\title{
Soft Skills as Employability Skills: Fundamental Requirement for Entry-level Jobs
}

$\sim$ Netra Bahadur Subedi ${ }^{1}$

\begin{abstract}
In spite of the fact that the term 'soft skills' is new in our context, it has a wide range of implications and effects. Soft skills are intangible, nontechnical, personality-specific skills that determine one's strengths as a leader, facilitator, mediator, and negotiator. Soft skills are contrasted to hard skills in a sense that hard skills are limited to specific area. It is to be noted that in the course of seeking an employment in the market, individual's soft skills are as important as hard skills. It is found that person's hard skills lead an individual to the entrance of job market, soft skills guarantee the job opportunity and further career growth. It is urgent that we have to instill our graduates with remarkable amount of soft skills for quick employment. It is always advisable that the companies select human resources with the best non-technical skills that are likely to be available in the labour market. It is further important to foster and develop the employees. Thus, these inter-sectional skills are really important for the promotion and enhancement of the organization. Owing to the same fact, this paper argues how soft skills as employability are fundamental requirement for entry-level Jobs.
\end{abstract}

Key Words: Soft Skills, EQ, Civic Sense, Social Graces, Technical Skills

\section{Opening the Window}

Nowadays people are much concerned about soft skills. Though it is a new term in the academia, business houses and government offices, it has been a buzz word. Particularly, in the western society, it had been matter of concern for many for the last few decades. However, in our context, it has been a new entry. In this connection, it is worthwhile to define this term. Soft skills are character traits, attitudes, and behaviors rather than technical aptitude or knowledge. Soft skills are the intangible, nontechnical, personality-specific skills that determine one's strengths as a leader, facilitator, mediator, and negotiator (Robes, 2012).

It is understandable that soft skills are all connected to people's character features, poise and conducts that contradict with technical knowledge. However, who bear public positions like leaders, managers and other agents are expected to have soft skills to a large extend because these qualities enhance their skills. Another definition states:

1 Subedi is an Assistant Professor at Koteshwor Multiple Campus (KMC). He teaches Poetry, plays and prose to the English Literature students at KMC. 
Soft skills is a sociological term relating to a person's "EQ (Emotional Intelligence Quotient)",the cluster of personality traits, social graces, communication, language, personal habits, friendliness, and optimism that characterize relationships with other people. Soft skills complement hard skills (part of a person's IQ), which are the occupational requirements of a job and many other activities (Moin, 2012).

It is obvious that soft skills is a sociological term that is associated to the Emotional Intelligence Quotient of an individuals that comprises personality features, civic sense, communication skills, people's habits and behaviours, amicability, interactivity etc. Contrary to this, hard skills, another traditionally speaking more important, occupational requirement of a job can be tested academically through summative tests. However, hard skills get well activated with the help of soft skills.

In modern academia and most of the recruiting companies the term soft skills is heavily used. Elsewhere also, we often hear people talking about it very recently. At the same time, we hear about it in many government offices. It is understandable that both hard skills and soft skills have become occupational requirements of a job/self-employment and many other areas. In a sense, soft skills are associated to feelings, insights and emotions very often known as inner knowing.

It is widely agreed that a person's soft skill is an important of his/her individual contribution to the success of any institutions. Organizations, particularly dealing with customers face to face can become more successful if they have their staffs with higher level of soft skills. For example, in legal profession, individual's ability to deal with people politely and effectively will guarantee the success of the concerned legal organization. It is an established fact that in many professions, soft skills contribute more than technical skills in the long run.

Research suggests that soft skills are just as good an indicator of job performance as traditional job qualifications (hard skills). Hard skills are the technical abilities and knowledge that one possesses, whereas soft skills are those personal attributes and interpersonal qualities that are intangible. Although soft skills are important to recognize and improve, hard skills are critical on the job as well. While employers exceedingly want new employees to possess strong soft skills, the hard and soft skills must complement one another (Robes, 2012).

In the past the recruiting companies only focused on hard skills, traditionally speaking job qualification. Needless to say, they comprise technical abilities and contents or knowledge. Contrary to this, soft skills are personal attributes and personal intangible qualities. In today's market both hard skills and soft skills are equally important. So to speak, soft skills complement the hard skills and vice-versa. 
A Soft Skill that most experts recognize such as a very important one is Emotional Intelligence. A possible definition of this transversal skill is the ability to perceive and express emotions, to understand and positively use them, and to effectively manage emotions in ourselves and others. Thus Emotional Intelligence is central to performance. It can be considered connected to individual personality but it can also be developed through attention and development (Kingsley, 2015).

Managing emotional intelligence is another specific area of soft skills. This intersectional skill has a concern with understanding, expressing and managing emotion in oneself and in others positively. So to speak, emotional intelligence is the crux of soft skills. It is directly connected to individual personality that grows in phases

\section{Hard Skills Vs. Soft Skills and Gaps}

Another fact about soft skills is that it is widely applicable to most areas. In another sense also, soft skills are contrasted to hard skills in a sense that hard skills are limited to an specific area. Therefore, in the course of seeking an employment in the market, individual's soft skills are as important as hard skills. It is often said that person's hard skills lead an individual to the entrance of job market, soft skills guarantee the job opportunity and further career growth. It gives the sense that while hiring people organizations seek candidates having both soft skills and hard skills. Whatever level of talent the people have, they cannot think and work constructively and critically without having a positive and can do attitude. It has been a long standing complaint of employers as well as the managers, that the newcomers i.e. students fresh out of college / universities lack soft skills and are unemployable. We hear a blame game between the schools and parents for the lack of soft skills in their wards.

This escalates into a situation where the colleges blame the parents and parents, on the other hand, feel that they have paid a heavy amount of fees to the college so it is their duty to teach the students Soft Skills. The result of this entire melee is each one tries to pass the buck to the other and as an end result; the students are the sufferers. They are really far behind in Etiquette \& Soft Skills. Predominantly missing amongst Soft Skill is the ability to communicate properly in the English language and express their views correctly and clearly(Dharmarajan, 2012). The ultimate result of this blame game is that the students are the real sufferers. Unfortunately, they are far behind in civic sense technically called etiquette and overall soft skills. Poor communication skills and terrible ways of information sharing will lead to disaster.

In this connection, I would relate my experience with TEVT (Technical Education and Vocational Traning) staffer, with whom I had an opportunity to talk for some times 
regarding the demand and supply of human resources in Nepali context with regard to soft skills. He responded that there is remarkable complaint from recruiting firms in that the available human resources are competent enough in terms of technical skills (hard skills) but are remarkably poor in terms of soft skills. This complaint is very strong in the market. I present another quote here:

Today's employers expect incoming hires to be prepared to immediately interact effectively in diverse teams. Attaching a leadership degree to any other major should help fill this current organizational deficit. From the student recruitment process through their graduation, this point should be made clear to all current and incoming students. This would allow students to decide early in their collegiate experience as to whether the additional cost and time for dual degrees is worth their pursuit (Brungardt, 2011).

The article states that the employees of modern era are expected to have been prepared to communicate and interact with diverse teams immediately after they are hired. The leadership quality instilled with non-technical skills will obviously fulfill the current deficit in an organization. The universities should consider this matter in the course of graduating their students, so that our current and incoming graduates will be made prepared for the future. Once they are made aware about the importance of soft skills in their future career, they can decide early whether they want to get further dual degree or not. It is them to decide whether they want to spend more money and time.

Putting this matter in high priority, TEVT has decided to implement some courses of soft skills in some programs. They thought that it was really necessary to take this step. Otherwise, the market would lose trust on them. As time has changed to a remarkable extent and the term 'soft skills' has become a buzz word in the academia and business arena, the recruiting firms have been more and more concerned about it. That was the reason why the firms and companies are filing complaints against TEVT with regard to non-technical skills.

The staffer told us that they are planning to implement the course of soft skills in other programs also. They have got the ultimate objective of implementing soft skills courses in all programs they are running. They have already advised the Ministry of Education to implement some courses of soft skills in school level also; so that we will be able to put some meaningful efforts to address this, otherwise dire, problem in the future.

Hard skills are the technical expertise and knowledge needed for a job. Soft skills are interpersonal qualities, also known as people skills, and personal attributes that one possesses. Business executives consider soft skills a very important attribute in job applicants. Employers want new employees to have strong soft skills, as well as hard skills(Robes, 2012). 
It is obvious that our academic institutions focus on hard skills, knowledge required for the job. Unlike this, soft skills are human skills very often known as interpersonal skills and personal qualities. Business companies, particularly, business executives take soft skills very important parameter for the promotion of any companies. Therefore, they consider soft skills prerequisites for job applicants. It is obvious, therefore, all employers expect their prospective employees to have strong soft skills.

Corporate recruiters want candidates with soft skills who add value with their soft skills, and also have the ability to make a difference in the workplace. Business employees need to communicate effectively, get along well with their coworkers, embrace teamwork, take initiative, have high work ethic, and portray professionalism (Robes, 2012).

As I have categorically mentioned above that the corporate houses want their prospective employees to bear soft skills to a great extent that will add value to their job. It is further expected that people with these skills will make remarkable differences. Particularly, employees in the corporate houses bear high level of communication skills, interactivity, ability to take initiatives, work ethics and professionalism. It is an established fact that teaching hard skills is an investment. In a similar fashion, it is advisable that soft skills also should be taught to the students as an investment. However, soft kills is very important in the work place, unfortunately, the employees today usually don't bear required interpersonal skills. Therefore, the organizations should train their employees on soft skills.

It is worthwhile to mention a discussion I had with a director of corporate house (H R Department) in Kathmandu. I would like to present it in the direct dialogue form.

I: How would you assess your employees during their entry?

M. D.: I find them very much promising, however, there is something lacking on them. I: Do you always select them on merit basis? Or, are there any other influencing factors? M. D.: Needless to say, we always select them on merit basis. They are well qualified and have been graduated with very high grades.

I: So to speak, they are very sound academically, aren't they?

M. D.: Of course, they are. They are really very much sound academically. But unfortunately, they lack some other skills, which, I believe, are important in the work place. Certain skills like positively responding people, politely questioning, serving people enthusiastically and timely providing feedback to the management are important in the workplace.

I: You mean to say, they lack certain level of soft skills. Did you mean so? 
M.D.: Obviously, I meant that, but didn't pronounce. They really lack soft skills, which are counted a lot in the workplace.

I: I hear the same kind of complaints from other companies also. Do you provide them trainings before you send them to the work? How long induction do you provide them?

M. D.: We provide them one to three day induction program to each employee before sending them to work. Our senior staff induct them before letting them handle their job independently. Talking about training, it is not possible to provide them training every time they are recruited because we usually recruit them in a small number each time. Providing them training in individual basis is not possible. We train them in bulk every six month or so. The junior staff usually get 5 day training whereas staff in the managerial level get 3 day training.

I: After such an induction and training, do you still have the same kind of complaints from your staff?

M. D. Of course, we still have the staff, particularly junior staff, lacking these skills. Senior staff are obviously smarter as we hire people with more exposure and training in the senior level

I: where do you think are the problems? With the individuals or with the colleges?

M.D. I believe that the problems are elsewhere. The universities should provide some courses on soft skills in each level. Some universities are already doing it. In India, there are so many training centres that provide practical training on soft skills to the new graduates before they join the job. In Nepal people are little aware about it. But, I believe, it is of dire need. At the same time, the family should be aware about it from the early life of their children. Since family is the first school, the children learn many things at home.

I: I think, your feedback is of great significance for my research. Thank you very much for providing your quality time. See you!

M. D. : Thank you sir! See you !

I present the following quote to continue it.

Plasticity is to develop and keep up-to-date in changing circumstances. Soft Skills are closely related to plastic, rational elaborating, abilities, elaborated in the prefrontal cortex, developed by Man in the last 50.000 years. Hard Skills allow Man to be what he is: an engineer, a physicist, a philosopher. Soft Skills operate in a direction that is rather separate from the role of the individual and go beyond the strict demands of the profession (Grisi, 2014).

Precisely speaking, soft skills are rational elaborating plastic skills that was developed by human beings in the course of thousands years of interaction. Hard skills leads 
people to the door of the job, soft skills guarantees them their career growth. However, soft skills operate in a separate direction of individual's profession, it has very high demand recently.

\section{Steps Ahead}

At this juncture, it is highly advisable that all concerned should work together to promote soft skills in the students, along with hard skills when they are graduated. Similarly, after that also the recruiting firms and corporate houses should refresh them with soft skills. In this regard, it is appropriate to discuss the following quote;

We would venture so far to suggest that the parents should be given regular training in Soft Skill and should be asked to monitor, and not police, their children and report back to the faculty. We all will agree that it would be a herculean task but at the same time it is going to give us the desired results within a short period of time. Moreover, Soft Skill training should begin at the primary school level and should continue till post graduation or at least till graduation. Almost all educational institutions force the students to pay more attention to technical subjects and leave the training of Soft Skills to the parents (Dharmarajan, 2012).

This journal article highlights that the focus should be on the parents rather than on the schools. But unfortunately, parents are not so much aware about this fact. Therefore, it is recommended that they should be given timely trainings so as to make them more aware about this fact. It is advised that the faculties should be reported. However, it is very difficult to do so, we should do it for amazing results within a very short period of time. In a similar fashion, in schools, too, soft skills trainings should be given to the parents of primary level. It would be worthwhile to continue it until graduation/post-graduation. Leaving soft skill trainings to the parents, educational institutions should force the students to be more attentive to concerned technical subjects.

Soft Skills are the need of the hour. It encourages all the participants of the existing modern world beginning from students, teachers to professionals. Learning of soft skill is a continuous process. In comparison to way or methods of learning soft skills, the interest in learning plays important role. Now through management course \& different types of training programmers are taken into hand by different well known Govt. \& Private organizations to make people aware of its importance \& utilization (Moin, 2012).

As stated previously, soft skills are the most important qualities in work places today. It is not essential to students and teachers only, but also to all professionals. As learning is 
a continuous process so is the case with soft skills. So to speak, soft skills also require lifelong learning. Interest in learning also counts a lot in this regard. Very recently, several items of soft skills are taught through the management courses particularly, in the higher levels. Additionally, government and private organizations sometimes make people aware about soft skills.

The challenge in education field these days rises as the cause of society's expectation for higher education. This increasingly complex expectation demands that higher education prepares the students to gain integrity. Higher education provides not only hard skills for the student, but also soft skills (Dewiyani S,2015).

At present, the society has entirely different expectations in the field of education. It is expected higher education prepares students with high level of integrity. Traditionally, their prime concern was to instill students with required technical skills. But in this modern time it won't be enough; apart from technical skills the students are to be instilled with non- technical skills, too. Similar the concept could be elaborated from the following quote:

The embrace of soft skills by education reformers is well in advance of the development of conceptual, instructional, measurement, and accountability models of soft skills that are appropriate to education settings. There is something important going on that should be incorporated into school reform. But we need to avoid a naïve bandwagon that pulls reform efforts in unproductive or detrimental directions. That, in turn, requires a program of work that will take some while to reach maturity. In the meantime, prudent policy and incremental experiments in practice are in order. (Whitehurst 2016).

The focus of education practitioners should be on the development of conceptual and instructional arena of soft skills. The further homework for them is to develop the soft skills model comprising of soft skills measurement and accountability. It is advisable that soft skills curricula should be incorporated into school reform. But at the same time, the educationists should be aware about the fact that this reform program should not be derailed. Another recommendation is that we have to wait for sometimes until the reform will get maturity. Further expectations are careful policy and proliferating experiments for the sustainable promotion of soft skills.

In order to obtain qualified degrees from higher education, soft skills should be mastered well, in addition to hard skills (knowledge and technical skills) studied during the study program. This is for the purpose of preparing the graduates of higher education to not only become skillful robots that lack of sense of humanities (Dewiyani S, 2015). 
This quote focuses, apart from technical skills, the students should be mastered with non- technical skills in the course of giving them higher education. If we do not focus on soft skills in the course of giving them higher education, we are most likely to produce heartless robots rather than human beings that are capable of managing their emotions.

\section{Conclusion}

At this turning point I remember the famous saying on timely decision making and their prompt execution; 'don't wait until tomorrow, when you can do it today. If we don't take some significant steps as a nation and as a knowledgeable community to promote non- technical skills in our graduates in the near future, we will further fall behind in human resource promotion and overall development of the nation.

It is evident the importance for any company to select human resources with the best Soft Skills available in the labour market and to go on fostering their development for employees once hired. Transversal competences are fundamental in order to allow any organization to work effectively and efficiently, then to reach a high quality of the products and the services offered. Even in industry, where the level of technology plays a particularly significant role, technical competences are not sufficient to correctly run the production: a coordination and harmony between employer and employees are fundamental to achieve the necessary level of quality to be competitive (Barbara, 2016).

It is always advisable that the companies select human resources with the best nontechnical skills that are likely to be available in the labour market. It is further important to foster and develop the employees. So to speak, these inter-sectional skills are really important for the promotion and enhancement of the organization. Needless to say, in any business organizations and other recruiting companies, technical skills alone do not suffice. Proper communication and coordination amongst the employees is highly desirable for accomplishing quality growth and promotion of an organization.

Based on the literature that I went through and from my own experience, I can say for sure that we are bound to promote soft skills in our schools and colleges. Otherwise, we will lose our grip in recruiting firms and companies. In the western society, the schools/colleges are emphasizing it to a great extent. Asian countries in general and India, in particular, are focusing on overall skills required for prospective job holders. Soft Skills has been incorporated in the syllabus of many Indian schools/colleges putting in mind the future prospect. Therefore, if we don't instill our future employees with overall skills, including soft skills, our firms/companies will be bound to recruit their employees from foreign countries, including India; thus, enforcing our unskilled/ 
skilled human resources seeking job in the foreign land, including India, Malaysia, Korea and golf countries. This gives a very dark picture of our future when we will be bound to pay more for the foreign employees and our citizens will be compelled to work in the foreign land in low salary. This reality shows the urgency to take some necessary actions.

\section{References}

Barbara. C. (2016).Definition, development, assessment of soft skills and their role for quality of organizations and enterprises. International Journal for Quality Research, 10(1).

Brungardt. C. (2011).The intersection between soft skill development and leadership education. Journal of Leadership Education,10 (1). Fort Hays State University

Dewiyani S, M. J.(2015. Improving students soft skills using thinking process profile based on personality types. International Journal of Evaluation and Research in Education (IJERE), 4(3). Institute of Business and Informatics Stikom Surabaya, Indonesia

Dharmarajan, P. V. Pachigalla, R. \&,Lanka, K. (2012). The significance of inculcating soft skills in students in the process of teaching hard skills. International Journal of Applied Research \& Studies, 1(2). Lucas- TVS, Chennai

Kingsley, B. (2015). Self awareness and emotional intelligence. Speech at "Soft Skills and their role in employability - New perspectives in teaching, assessment and certification", workshop in Bertinoro, FC, Italy.

Moin, R. \&Biswal, S. (2012). Soft skills in status quo. International Journal of Physical and Social Sciences, 2 (5). Open J-Gage, India.

Robes, M.M. (2012).The top 10 soft skills needed in today's workplace. Business Communication Quarterly 75(4) 453-465. Sage.

Whitehurst, G.J.(2016). Hard thinking on soft skills. Economic Studies at Brooking. $1(14)$ 